\title{
Faktor - Faktor Yang Mempengaruhi Cakupan Asi Eksklusif Di Wilayah Kerja Puskesmas Sidomulyo Kecamatan Tampan
}

\author{
Ulfa Amalia, Yufitriana Amir, Lita \\ Program Studi Ilmu Keperawatan Sekolah Tinggi Ilmu Kesehatan (STIKes) Hang Tuah, Jl. Mustafa Sari \\ No. 5 Tangkerang Selatan Pekanbaru, Riau - 28000. \\ E-mail: ulfamaliazurham@gmail.com
}

\begin{abstract}
Six months exclusive breastfeeding is the best for improving baby's growth and development. The current phenomenon found that coverage of exclusive breastfeeding at Sidomulyo Health Care is too low, which is only 31\%. This research aimed to identify factors that associated with exclusive breastfeeding coverage in Sidomulyo Health Center, Tampan district. The retrospective approach with cluster sampling method is used to this study, with 136 people from 469 populations was taken as sample. Fisher's exact test and Chi-square test were used for statistical test. The univariate analysis showed that 55.1\% of the mothers were within the age range of 26-35; 52.9\% of women had a high school diploma; 46.3\% categorized as malay people; $65.4 \%$ were housewives/unemployed; 68.4\% mothers got source support from husbands; and $91.2 \%$ identified as healthy mothers. Other factors were also considered such as 75\% mothers identified cultural factors influencing their decision to breastfed; $90.4 \%$ of the mothers had good knowledge of EBF; 69.9\% families supporting exclusive breastfeeding; and 62.5\% mothers gave non-exclusive breastfeeding. Along with that, bivariate analysis results indicate that breastfeeding efficacy was significantly related to: age $\left(P_{\text {value }}=0.014\right)$, sociocultural $\left(P_{\text {value }}=0.011\right)$ and maternal health $\left(P_{\text {value }}=0.031\right)$. Meanwhile, unrelated variables were: education $\left(P_{\text {value }}=0.549\right) ;$ knowledge $\left(P_{\text {value }}=0.766\right) ;$ occupation $\left(P_{\text {value }}=0.745\right)$; and family support $\left(P_{\text {value }}=0.267\right)$. More improvement on exclusive breastfeeding can increase among young mothers, as well as their supportive sociocultural and the awareness about maternal health.
\end{abstract}

References : 24 (2008-2017)

Keywords : Exclusive breastfeeding, age, education, family support, level of knowledge, maternal health, occupation, sociocultural.

\section{ABSTRAK}

Air susu ibu (ASI) eksklusif semestinya diberikan sesaat bayi lahir hingga usia 6 bulan karena ASI eksklusif sangat baik bagi perkembangan dan pertumbuhan bayi. Fenomena saat ini masih rendahnya cakupan ASI eksklusif, khususnya di wilayah kerja Puskesmas Sidomulyo Kecamatan Tampan yaitu hanya 31\%. Penelitian ini bertujuan mengetahui faktor - faktor apa saja yang mempengaruhi cakupan ASI eksklusif di wilayah kerja Puskesmas Sidomulyo Kecamatan Tampan. Pendekatan yang digunakan dalam penelitian adalah pendekatan retrospektif dengan teknik cluster sampling. Penelitian dilakukan di wilayah kerja Puskesmas Sidomulyo Kecamatan Tampan dengan populasi 469 orang dan sampel 136 orang. Uji statistik yang digunakan adalah uji chi-square dan fisher. Hasil analisa univariat diperoleh mayoritas ibu berusia 26-35 tahun (55.1\%), berpendidikan SMA/SLTA (52.9\%), bersuku melayu (46.3\%), IRT/tidak bekerja (65.4\%), sumber dukungan berasal dari suami $(68.4 \%)$ dan ibu yang sehat $(91.2 \%)$. Ibu yang memiliki sosial budaya yang mendukung pemberian ASI eksklusif (75\%), tingkat pengetahuan ibu yang baik mengenai ASI eksklusif (90.4\%), keluarga yang mendukung pemberian ASI eksklusif (69.9\%), serta ibu yang tidak ASI eksklusif $(62,5 \%)$. Hasil analisa bivariat menunjukkan variabel yang berhubungan terhadap pemberian ASI eksklusif yaitu, usia dengan $P_{\text {value }}=0.014$, sosial budaya dengan $P_{\text {value }}=0.011$ dan kesehatan ibu dengan $P_{\text {value }}=0.031$ serta variabel yang tidak berhubungan terhadap pemberian ASI ekskluisf yaitu, pendidikan dengan $P_{\text {value }}$ $=0.549$, tingkat pengetahuan dengan $P_{\text {value }}=0.766$, pekerjaan dengan $P_{\text {value }}=0.745$ dan dukungan keluarga dengan $P_{\text {value }}=$ 0.267. Diharapkan pemberian ASI eksklusif ini dapat meningkat pada ibu yang berusia 26-35 tahun, ibu yang memiliki sosial budaya yang mendukung serta pada ibu yang sehat.

Daftar Pustaka Kata kunci
: 24 (2008-2017)

: ASI eksklusif, dukungan keluarga, kesehatan ibu, pekerjaan, pendidikan, sosial budaya, tingkat pengetahuan, usia. 


\section{Pendahuluan}

Zat gizi yang pertama sekali diberikan kepada bayi saat lahir adalah air susu ibu (ASI) melalui proses inisiasi menyusui dini. Gizi yang dibutuhkan bayi usia 0 bulan hingga 6 bulan untuk proses tumbuh kembang telah tercukupi dari pemberian ASI. ASI adalah makanan alamiah yang merupakan makanan pertama, utama dan makanan terbaik bagi seorang bayi yang mengandung berbagai nutrisi yang diperlukan bayi untuk proses pertumbuhan dan perkembangan. ASI memiliki keunggulan dari nilai gizi yang terkandung didalamnya. ASI dapat meningkatkan kekebalan tubuh bayi dan memberikan perlindungan pada bayi terhadap berbagai penyakit bakteri dan virus sehingga pemberian ASI eksklusif sangat dianjurkan (Riksani, 2012).

ASI eksklusif merupakan pemberian ASI kepada bayi usia 0-6 bulan tanpa memberikan makanan tambahan lain dalam bentuk apapun. WHO dan Departemen Kesehatan Republik Indonesia menetapkan rekomendasi pemberian ASI eksklusif selama 6 bulan untuk menunjang pertumbuhan, perkembangan dan kesehatan yang optimal (Prasetyono, 2012).

Target cakupan ASI eksklusif oleh WHO tahun 2012 adalah 50\% dan target cakupan ASI eksklusif di Indonesia berdasarkan renstra tahun 2016 adalah 42\%. Data WHO tahun 2014 menunjukkan cakupan ASI eksklusif dunia masih 38\%. Berdasarkan Kemenkes RI tahun 2016 pemberian ASI eksklusif secara nasional hanya 29.5\% dengan pencapaian ASI eksklusif di Provinsi Riau hanya 25\%. Menurut Profil Kesehatan Provinsi Riau tahun 2016, sebanyak 20 wilayah kerja puskesmas di Kota Pekanbaru, 19 diantaranya telah mencapai target, akan tetapi masih terdapat 1 wilayah kerja puskesmas dengan cakupan pemberian ASI eksklusif yang belum mencapai target yaitu hanya 31\% yang terdapat pada wilayah kerja Puskesmas Sidomulyo Kecamatan Tampan.

Cakupan ASI eksklusif dipengaruhi oleh faktor eksternal maupun internal ibu. Menurut penelitian Arifiati (2017) terdapat hubungan antara pekerjaan, pengetahuan, dukungan keluarga, dan dukungan tenaga kesehatan dengan pemberian ASI eksklusif pada bayi di Kelurahan Warnasari Kecamatan Citangkil tahun 2014. Menurut penelitian Satino dan Setyorini (2014), terdapat pula pengaruh antara umur, pekerjaan, pendidikan, pengetahuan, perilaku dan lingkungan terhadap pemberian ASI eksklusif. Menurut Rahmawati (2010) faktorfaktor yang mempengaruhi pemberian ASI di Kelurahan Pedalangan Kecamatan Banyumanik Kota Semarang yaitu usia, pekerjaan, urutan kelahiran bayi dan dukungan petugas kesehatan.

Berdasarkan studi pendahuluan di Puskesmas Sidomulyo Kecamatan Tampan, dari 789 bayi usia 0-5 bulan yang terdata di Puskesmas Sidomulyo yang mendapatkan ASI eksklusif hanya 219 (27.75\%) bayi dan 570 (72.24\%) bayi tidak mendapatkan ASI eksklusif. Menuru tenaga kesehatan di Puskesmas Sidomulyo, beberapa faktor yang paling berpengaruh pada pemberian ASI eksklusif di masyarakat Puskesmas Sidomulyo adalah kurangnya pengetahuan ibu, pekerjaan ibu dan dukungan keluarga. Berdasarkan latar belakang di atas, maka peneliti tertarik untuk mengetahui apa saja "faktor - faktor yang mempengaruhi cakupan ASI eksklusif di wilayah kerja Puskesmas Sidomulyo Kecamatan Tampan".

\section{Metode Penelitian}

Penelitian ini menggunakan desain retrospektif dengan teknik cluster sampling. Penelitian dilakukan di wilayah kerja Puskesmas Sidomulyo Kecamatan Tampan dengan populasi 469 orang dan sampel 136 responden. Alat pengumpulan data menggunakan kuesioner. Uji statistik menggunakan uji chi-square dan fisher exact.

\section{Hasil dan Pembahasan}




\section{Analisa Univariat}

1. Karakteristik Responden

\begin{tabular}{llcc}
\hline No & \multicolumn{1}{c}{ Variabel } & $f$ & $\%$ \\
\hline 1 & Usia & & \\
& $\begin{array}{l}\text { a. Remaja akhir (17-25 } \\
\text { tahun) }\end{array}$ & 18 & 13.2 \\
& $\begin{array}{l}\text { b. } \begin{array}{l}\text { Dewasa awal (26-35 } \\
\text { tahun) }\end{array} \\
\text { c. Dewasa akhir (36-45 } \\
\quad \text { tahun) }\end{array}$ & 75 & 55.1 \\
\hline 2 & Pendidikan & 31.6 \\
\end{tabular}

a. Rendah (SD-SMP) $\quad 22 \quad 16.2$

b. Sedang (SMA/SLTA) $72 \quad 52.9$

$\begin{array}{lll}\text { c. Tinggi (Perguruan } & 42 & 30.9\end{array}$

tinggi)
3 Jenis pekerjaan
a. PNS
$16 \quad 11.8$
b. Wiraswasta
$12 \quad 8.8$
c. Swasta
$19 \quad 14.0$
d. IRT/Tidak bekerja
$89 \quad 65.4$

$4 \quad$ Suku
a. Melayu
$63 \quad 46.3$
b. Minang
$27 \quad 19.9$
c. Jawa
$38 \quad 27.9$
d. Batak
$8 \quad 5.9$

\begin{tabular}{|lrr|}
\hline 5 & \multicolumn{2}{l}{$\begin{array}{l}\text { Sumber utama dukungan } \\
\text { keluarga }\end{array}$} \\
\hline a. Suami & 93 & 68.4 \\
b. Orangtua & 7 & 5.1 \\
c. Teman & 4 & 2.9 \\
d. Lebih dari satu & 32 & 23.5
\end{tabular}

6 Kesehatan ibu

a. Sehat

$124 \quad 91.2$

b. Tidak sehat

$12 \quad 8.8$

Jumlah

$136 \quad 100$

Distribusi frekuensi karakteristik responden yaitu, mayoritas responden berusia 26-35 tahun 75 (55.1\%) responden, berpendidikan SMA/SLTA 72 (52.9\%) responden, bersuku melayu 63 (46.3\%) responden, IRT/tidak 
bekerja 89 (65.4\%) responden, sumber dukungan berasal dari suami 93 (68.4\%) responden serta ibu yang sehat $124(91.2 \%)$ responden.

2. Sosial budaya

\begin{tabular}{clcc}
\hline No & Sosial budaya & $f$ & $\%$ \\
\hline 1 & Mendukung & 102 & 75.0 \\
2 & Tidak mendukung & 34 & 25.0 \\
\hline & Jumlah & 136 & 100.0
\end{tabular}

Distribusi frekuensi responden berdasarkan dukungan sosial budaya menunjukkan 102 (75.0\%) responden memiliki sosial budaya yang mendukung.

3. Tingkat pengetahuan

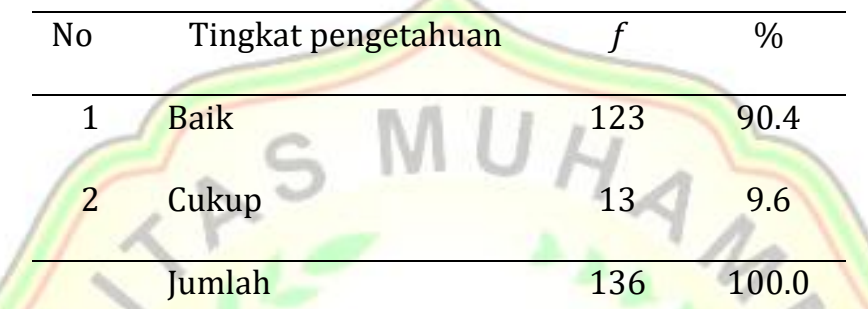

Distribusi frekuensi responden berdasarkan tingkat pengetahuan menunjukkan tingkat pengetahuan responden terbanyak adalah baik yaitu 123 (90.4\%) responden.

4. Dukungan keluarga

\begin{tabular}{clcc}
\hline No & Dukungan keluarga & $f$ & $\%$ \\
\hline 1 & Mendukung & 95 & 69.9 \\
2 & Tidak mendukung & 41 & 30.1 \\
\hline & Jumlah & 136 & 100.0
\end{tabular}

Distribusi frekuensi responden berdasarkan dukungan keluarga menunjukkan 95 (69.9\%) responden memiliki keluarga yang mendukung.

5. Pemberian ASI

\begin{tabular}{clcc}
\hline No & Pemberian ASI & $f$ & $\%$ \\
\hline 1 & Eksklusif & 51 & 37.5 \\
2 & Tidak eksklusif & 85 & 62.5 \\
& & & \\
\hline & Jumlah & 136 & 100.0
\end{tabular}

Distribusi frekuensi responden berdasarkan pemberian ASI menunjukkan 85 (62.5\%) responden tidak memberikan ASI eksklusif. 


\section{Analisa Bivariat}

1. Hubungan usia dengan pemberian ASI eksklusif

\begin{tabular}{|c|c|c|c|c|c|c|c|}
\hline \multirow[t]{3}{*}{ Usia Ibu } & \multicolumn{6}{|c|}{ Pemberian ASI } & \multirow{3}{*}{$\begin{array}{c}P \\
\text { value }\end{array}$} \\
\hline & \multicolumn{2}{|c|}{ Eksklusif } & \multicolumn{2}{|c|}{ Tidak eksklusif } & \multicolumn{2}{|c|}{ Jumlah } & \\
\hline & $\mathrm{n}$ & $\%$ & $\mathrm{n}$ & $\%$ & $\mathrm{n}$ & $\%$ & \\
\hline $\begin{array}{l}\text { Remaja akhir } \\
\text { (17-25 tahun) }\end{array}$ & 3 & 16.7 & 15 & 83.3 & 18 & 100 & 0.014 \\
\hline $\begin{array}{l}\text { Dewasa awal } \\
\text { (26-25 tahun) }\end{array}$ & 36 & 48.0 & 39 & 52.0 & 75 & 100 & \\
\hline $\begin{array}{l}\text { Dewasa akhir } \\
\text { (36-45 tahun) }\end{array}$ & 12 & 27.9 & 31 & 72.1 & 43 & 100 & \\
\hline Jumlah & 51 & & 85 & & 136 & & \\
\hline
\end{tabular}

Uji chi-square didapatkan $P_{\text {value }}=0.014$, hal ini menunjukkan terdapat hubungan antara usia dengan pemberian ASI eksklusif.

2. Hubungan pendidikan dengan pemberian ASI eksklusif

\begin{tabular}{|c|c|c|c|c|c|c|c|}
\hline \multirow[t]{3}{*}{ Pendidikan Ibu } & \multicolumn{6}{|c|}{ Pemberian ASI } & \multirow{3}{*}{$\begin{array}{c}P \\
\text { value }\end{array}$} \\
\hline & \multicolumn{2}{|c|}{ Eksklusif } & \multicolumn{2}{|c|}{ Tidak eksklusif } & \multicolumn{2}{|c|}{ Jumlah } & \\
\hline & n & $\%$ & n & $\%$ & n & $\%$ & \\
\hline $\begin{array}{l}\text { Rendah } \\
\text { (SD-SMP) }\end{array}$ & 6 & 27.3 & 16 & 72.7 & 22 & 100 & 0.549 \\
\hline $\begin{array}{l}\text { Sedang } \\
\text { (SMA/SLTA) }\end{array}$ & 28 & 38.9 & 44 & 61.1 & 72 & 100 & \\
\hline $\begin{array}{l}\text { Tinggl } \\
\text { (Perguruan } \\
\text { Tinggi) }\end{array}$ & 17 & 40.5 & 25 & $59.5^{\circ}$ & 42 & 100 & \\
\hline Jumlah & 51 & & 85 & & 136 & & \\
\hline
\end{tabular}

Uji chi-square didapatkan $P_{\text {value }}=0.549$, hal ini menunjukkan tidak ada hubungan antara pendidikan dengan pemberian ASI eksklusif.

3. Hubungan sosial budaya dengan pemberian ASI eksklusif

\begin{tabular}{|c|c|c|c|c|c|c|c|c|}
\hline \multirow{3}{*}{$\begin{array}{l}\text { Sosial } \\
\text { Budaya }\end{array}$} & \multicolumn{6}{|c|}{ Pemberian ASI } & \multirow{3}{*}{$\begin{array}{c}P \\
\text { value }\end{array}$} & \multirow[t]{2}{*}{ POR } \\
\hline & \multicolumn{2}{|c|}{ Ekskilusif } & \multicolumn{2}{|c|}{ Tidak eksklusif } & \multicolumn{2}{|c|}{ Jumlah } & & \\
\hline & n & $\%$ & $\mathrm{~N}$ & $\%$ & n & $\%$ & & \\
\hline Mendukung & 45 & 44.1 & 57 & 55.9 & 102 & 100 & 0.011 & 3.684 \\
\hline $\begin{array}{l}\text { Tidak } \\
\text { mendukung }\end{array}$ & 6 & 17.6 & 28 & 82.4 & 34 & 100 & & \\
\hline Jumlah & 51 & & 85 & & 136 & & & \\
\hline
\end{tabular}

Uji chi-square didapatkan $P_{\text {value }}=0.011$, hal ini menunjukkan terdapat hubungan antara sosial budaya dengan pemberian ASI eksklusif.

4. Hubungan tingkat pengetahuan dengan pemberian ASI eksklusif 


\begin{tabular}{|c|c|c|c|c|c|c|c|c|}
\hline \multirow{3}{*}{$\begin{array}{c}\text { Tinglat } \\
\text { pengethuan }\end{array}$} & \multicolumn{6}{|c|}{ Pemberian ASI } & \multirow{2}{*}{$\begin{array}{c}P \\
\text { value }\end{array}$} & POR \\
\hline & \multicolumn{2}{|c|}{ Exskdusifif } & \multicolumn{2}{|c|}{ Tidak exsdusif } & \multicolumn{2}{|c|}{ Jumlah } & & \\
\hline & $\mathrm{N}$ & $\%$ & $N$ & $\%$ & n & $\%$ & & \\
\hline Balk & 47 & $\overline{38.2}$ & 76 & 61.8 & 123 & 100 & 0.766 & \\
\hline Cuklup & 4 & 30.8 & 9 & 69.2 & 13 & 100 & & \\
\hline Jumlah & 51 & & 85 & & 136 & & & \\
\hline
\end{tabular}

Uji chi-square didapatkan $P_{\text {value }}=0.766$, hal ini menunjukkan tidak ada hubungan antara tingkat pengetahuan dengan pemberian ASI eksklusif.

5. Hubungan pekerjaan dengan pemberian ASI eksklusif

\begin{tabular}{|c|c|c|c|c|c|c|c|c|}
\hline \multirow[t]{3}{*}{ Pekerjan } & \multicolumn{6}{|c|}{ Pemberian ASI } & \multirow{3}{*}{ value } & \multirow[t]{3}{*}{ POR } \\
\hline & & & Tidake el & & & & & \\
\hline & $\mathrm{N}$ & $\%$ & $\mathrm{~N}$ & $\%$ & n & $\%$ & & \\
\hline Bekeria & 19 & 40.4 & 28 & 59.6 & 47 & 100 & 0.745 & \\
\hline Tidak belerena & 32 & 36.0 & 57 & 64.0 & 89 & 100 & & \\
\hline Jumlah & 51 & & 85 & & 136 & & & \\
\hline
\end{tabular}

Uji chi-square didapatkan $P_{\text {value }}=0.745$, hal ini menunjukkan tidak ada hubungan antara pekerjaan ibu dengan pemberian ASI eksklusif.

6. Hubungan dukungan keluarga dengan pemberian ASI eksklusif

\begin{tabular}{|c|c|c|c|c|c|c|c|c|}
\hline \multirow{3}{*}{$\begin{array}{l}\text { Dulumgand } \\
\text { keluarga }\end{array}$} & \multicolumn{6}{|c|}{ Pemberian ASI } & \multirow{3}{*}{ value } & \multirow{2}{*}{ POR } \\
\hline & & dusifi & & sklusif & & & & \\
\hline & 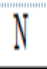 & $\%$ & II & $\%$ & $\llbracket$ & $\%$ & & \\
\hline Mendukung & 39 & 41.1 & 56 & 58.9 & 95 & 100 & 0.267 & 1.683 \\
\hline $\begin{array}{l}\text { Tidad } \\
\text { mendulung }\end{array}$ & 12 & 29.3 & 29 & 70.7 & 41 & 100 & & \\
\hline Jumlah & $5 !$ & & 85 & & 136 & & & \\
\hline
\end{tabular}

Uji chi-square didapatkan $P_{\text {value }}=0.267$, hal ini menunjukkan tidak ada hubungan antara dukungan keluarga dengan pemberian ASI eksklusif.

7. Hubungan kesehatan ibu dengan pemberian ASI eksklusif

\begin{tabular}{|c|c|c|c|c|c|c|c|}
\hline \multirow{3}{*}{$\begin{array}{c}\text { Kesechatan } \\
\text { Ibus }\end{array}$} & \multicolumn{6}{|c|}{ Pemberanan ASI } & \\
\hline & \multicolumn{2}{|c|}{ Exusdusisf } & \multicolumn{2}{|c|}{ Tidake exskilusif } & \multicolumn{2}{|c|}{ Jumlah } & \\
\hline & 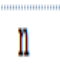 & $\%$ & 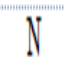 & $\%$ & $\llbracket$ & $\%$ & value \\
\hline Tidar selatat & 1 & 8.3 & 11 & 91.7 & 12 & 100 & 0.031 \\
\hline Selatat & 50 & 40.3 & 74 & 59.7 & 124 & 100 & \\
\hline Jumlah & $5 !$ & & 85 & & 136 & & \\
\hline
\end{tabular}

Uji chi-square didapatkan $P_{\text {value }}=0.031$, hal ini menunjukkan ada hubungan antara kesehatan ibu dengan pemberian ASI eksklusif.

\section{Pembahasan}




\section{Analisa Bivariat}

1. Hubungan usia dengan pemberian ASI eksklusif

Usia merupakan faktor yang mempengaruhi kesiapan ibu dalam memberikan ASI eksklusif pada bayi. Ibu berusia matang tentu akan memiliki kesiapan yang lebih baik dari segi emosional maupun fisik dibandingkan dengan ibu yang masih berusia 18 tahun ke bawah ataupun ibu yang telah berusia diatas 40 tahun karena kondisi fisik sudah mulai berkurang (Maritalia, 2014).

Teori ini sejalan dengan hasil penelitian dimana persentase pemberian ASI eksklusif yang tertinggi terletak pada usia dewasa awal (26-35 tahun) yaitu sebesar 48\%, dengan jumlah responden sebanyak 36 orang. Kelompok usia remaja akhir (17-25 tahun) dan dewasa akhir (36-45 tahun) memiliki persentase ASI eksklusif yang rendah apabila dibandingkan dengan kelompok usia dewasa awal (26-35 tahun). Hal ini disebabkan pada usia ini ibu sudah matang dan memiliki kesiapan baik dari segi fisik maupun emosional serta ibu dalam masa produktif.

2. Hubungan pendidikan dengan pemberian ASI eksklusif

Hasil penelitian menunjukkan persentase pemberian ASI eksklusif yang tertinggi terletak pada responden dengan pendidikan tinggi yaitu sebesar $40.5 \%$, dengan jumlah responden sebanyak 17 orang, pada responden dengan pendidikan sedang (SMA/SLTA) memiliki persentase ASI eksklusif yaitu sebesar 38.9\% dengan jumlah responden sebanyak 28 orang dan persentase ASI eksklusif terendah terletak pada responden dengan pendidikan rendah (SD-SMP) yaitu hanya 27.3\% dengan jumlah responden sebanyak 6 orang. Kesimpulan yang dapat diambil adalah semakin tinggi pendidikan maka semakin tinggi pula jumlah pemberian ASI eksklusif.

Hal ini sejalan dengan teori dimana ibu yang memiliki tingkat pendidikan yang tinggi tentu saja akan memiliki pengetahuan dan wawasan yang lebih luas. Pengetahuan ibu yang baik akan mendukung ibu dalam memberikan ASI eksklusif kepada bayinya mengingat betapa pentingnya kandungan ASI untuk pertumbuhan dan perkembangan bayi (Maritalia, 2014).

3. Hubungan sosial budaya dengan pemberian ASI eksklusif

Hasil penelitian menunjukkan bahwa dari 136 responden, 102 responden (75\%) memiliki sosial budaya yang mendukung, sedangkan 34 responden (25\%) lainnya memiliki sosial budaya yang tidak mendukung. Sosial budaya yang mendukung memiliki persentase ASI eksklusif yang tertinggi, yaitu sebesar 44.1\% dengan jumlah responden sebanyak 45 orang, sedangkan sosial budaya yang tidak mendukung memiliki persentase ASI eksklusif yang terendah, yaitu hanya 17.6\% dengan jumlah responden sebanyak 6 orang.

Semakin mendukung sosial budaya ibu maka semakin tinggi pula angka pemberian ASI eksklusif, sebaliknya semakin sosial budaya tidak mendukung maka semakin rendah pula angka pemberian ASI eksklusifnya. Sosial budaya yang mendukung cenderung akan mendorong ibu untuk memberikan ASI eksklusif pada bayi.

Hasil penelitian ini sesuai dengan teori yaitu Indonesia terdiri dari berbagai suku dan budaya yang beraneka ragam. Setiap suku memiliki kebudayaan dan tradisinya sendiri - sendiri dalam menghadapi ibu yang baru saja melahirkan dan akan menyusui bayinya. Sebagian besar suku dan budaya di Indonesia mendukung dan menganjurkan pemberian ASI eksklusif pada bayi (Maritalia, 2014).

4. Hubungan tingkat pengetahuan dengan pemberian ASI eksklusif

Hasil uji statistik menunjukkan bahwa persentase pemberian ASI eksklusif yang tertinggi terletak pada responden dengan tingkat pengetahuan yang baik yaitu sebesar 38.2\%, dengan jumlah responden sebanyak 47 orang, sedangkan pada responden dengan tingkat pengetahuan cukup hanya memiliki persentase ASI eksklusif 
yaitu sebesar $30.8 \%$ dengan jumlah responden sebanyak 4 orang. Kesimpulan yang dapat diambil adalah semakin baik tingkat pengetahuan maka semakin tinggi pula jumlah pemberian ASI eksklusif.

Hasil penelitian ini menunjukkan bahwa sebagian besar responden telah memiliki tingkat pengetahuan yang baik. Ibu - ibu yang memiliki tingkat pengetahuan yang baik telah mengetahui dan memahami mengenai ASI eksklusif dan manfaat ASI eksklusif bagi bayi. Hal ini di dukung dengan teori yaitu telah dilaksanakannya program pemerintah dan puskesmas untuk mensosialisasikan pentingnya pemberian ASI eksklusif pada bayi melalui penyuluhan dan pendidikan kesehatan (Prasetyono, 2012).

\section{Hubungan pekerjaan dengan pemberian ASI eksklusif}

Berdasarkan uji statistik didapatkan hasil bahwa pemberian ASI eksklusif tertinggi yaitu pada ibu yang bekerja yaitu sebesar $40.4 \%$ dengan jumlah responden sebanyak 19 orang, sedangkan pada ibu yang tidak bekerja pemberian ASI eksklusif hanya sebesar 36\% dengan jumlah responden sebanyak 32 orang. Pemberian ASI tidak eksklusif justru lebih tinggi pada ibu yang tidak bekerja yaitu sebesar 64\% dengan jumlah responden sebanyak 57 orang apabila dibandingkan dengan ibu yang bekerja hanya sebesar 59.6\% dengan jumlah responden sebanyak 28 orang.

Seiring dengan berjalannya waktu dan semakin meningkatnya kemajuan teknologi, pemberian ASI eksklusif pada bayi bagi ibu yang bekerja dapat dilakukan dengan cara memerah ASI. Memerah ASI adalah salah satu solusi yang dapat diterapkan oleh ibu pekerja yang tetap ingin memberikan ASI pada bayi mereka (Prasetyono, 2012). Teori tersebut dapat mendukung hasil penelitian dimana ibu yang bekerja tetap dapat memberikan ASI eksklusif pada bayi sehingga angka pemberian ASI eksklusif pada ibu yang bekerja lebih tinggi dari pada ibu yang tidak bekerja.

6. Hubungan dukungan keluarga dengan pemberian ASI eksklusif

Hasil uji statistik menunjukkan bahwa dari 136 responden, 95 responden (69.9\%) memiliki keluarga yang mendukung pemberian ASI eksklusif, sedangkan 41 responden (30.1\%) lainnya memiliki keluarga yang tidak mendukung. Keluarga yang mendukung memiliki persentase ASI eksklusif yang tertinggi, yaitu sebesar 41.1\% dengan jumlah responden sebanyak 39 orang.

Hasil penelitian ini sesuai dengan teori dimana 50\% keberhasilan pemberian ASI secara eksklusif juga ditentukan oleh peran keluarga terutama suami. Suami berperan penting untuk menciptakan suasana senyaman dan sekondusif mungkin bagi ibu untuk memberikan ASI eksklusif pada bayi agar proses menyusui dapat berjalan lancar. Anggota keluarga lain seperti orangtua juga sangat berpengaruh dalam hal ini. Orangtua tentu saja telah melewati proses ini terlebih dahulu, sehingga banyak informasi dan dukungan secara lisan maupun praktik diberikan oleh keduanya pada ibu saat menyusui. Upaya sederhana yang bisa dilakukan oleh kerabat dekat, saudara dan teman adalah memberikan informasi penting mengenai ASI eksklusif dan berbagai manfaat yang bisa bayi dan ibu didapatkan. Semakin baik dukungan yang didapatkan ibu maka semakin besar pula peluang ibu untuk memberikan ASI eksklusif pada bayi (Riksani, 2012).

7. Hubungan kesehatan ibu dengan pemberian ASI eksklusif

Hasil penelitian didapatkan bahwa persentase pemberian ASI eksklusif yang tertinggi terletak pada kelompok responden yang sehat yaitu sebesar $40.3 \%$, dengan jumlah responden sebanyak 50 orang, sedangkan pada kelompok responden yang tidak sehat persentase ASI eksklusif hanya sebesar 8.3\% dengan jumlah responden sebanyak 1 orang. Persentase tidak eksklusif yang tertinggi terletak pada kelompok yang tidak sehat yaitu sebesar $91.7 \%$ dengan jumlah responden 11 orang. 
Hasil penelitian ini sesuai dengan teori dimana kesehatan ibu sangat berpengaruh pada pemberian ASI eksklusif pada bayi. Beberapa gangguan pada kesehatan ibu yang dapat menghambat pemberian ASI eksklusif, yaitu puting lecet dan mastitis. Puting lecet merupakan masalah kesehatan karena trauma saat menyusui yang akan sembuh sendiri dalam waktu 48 jam sehingga tidak ada alasan bagi ibu untuk menghentikan pemberian ASI eksklusif (Dewi dan Sunarsih, 2011). Mastitis atau peradangan payudara adalah masalah kesehatan yang disebabkan oleh produksi ASI yang tinggi akan tetapi tidak seimbang dengan pengeluaran saat menyusui. Walaupun demikian, pemberian ASI eksklusif tetap dianjurkan karena salah satu penyebab mastitis adalah terhentinya produksi ASI sehingga meneruskan pemberian ASI sangat dianjurkan untuk mencegah mastitis jatuh ke keadaan yang lebih parah (Riksani, 2012).

\section{Kesimpulan}

Hasil penelitian yang telah dilakukan tentang Faktor - Faktor yang Mempengaruhi Cakupan ASI Eksklusif di Wilayah Kerja Puskesmas Sidomulyo Kecamatan Tampan menunjukkan bahwa variabel yang berhubungan terhadap pemberian ASI eksklusif yaitu, usia dengan $p_{\text {value }}=0.014$, sosial budaya dengan $p_{\text {value }}=0.011$ dan kesehatan ibu dengan $p_{\text {value }}=0.031$ serta variabel yang tidak berhubungan terhadap pemberian ASI ekskluisf yaitu, pendidikan dengan $p_{\text {value }}=0.549$, tingkat pengetahuan dengan $p_{\text {value }}=0.766$, pekerjaan dengan $p_{\text {value }}=0.745$ dan dukungan keluarga dengan $p_{\text {value }}=0.267$.

\section{Daftar Pustaka}

Abdullah, N. (2013). Meminimalisasi bullying di sekolah. MAGISTRA, 25(83), 50.

Dewi, H, E. (2012). Memahami Perkembangan Fisik Remaja. Yogyakarta: Gosyen Publishing.

Fatmawati, L., \& Uyun, Z. (2016). Perbedaan Perilaku Bullying Di Tinjau Dari Jenis Kelamin (Doctoral dissertation, Universitas Muhammadiyah Surakarta).

Herdyanti, F., \& Margaretha, M. (2016). Hubungan Antara Konsep Diri Dengan Kecenderungan Menjadi Korban Bullying Pada Remaja Awal. Jurnal Psikologi Undip, 15(2), 92-98.

Khoirunnisa, R. (2015). Konsep Diri Remaja Korban Bullying (Studi pada Siswa Korban Bullying di SMA Muhammadiyah 7 Yogyakarta). Jurnal Riset Mahasiswa Bimbingan Dan Konseling.

Komisi Perlindungan Anak Indonesia. (2016). Bully SMA 3, Kedatangan Tim KPAI Ditolak Pihak Sekolah. Jakarta : KPAI. Diperoleh dari http://www.kpai.go.id/berita/bully-sma-3-kedatangan-tim-kpai-ditolak-pihak-sekolah/

Komisi Perlindungan Anak Indonesia. (2017). KPAI Terima Aduan 26 Ribu Kasus Bully Selama 2011-2017. Jakarta : KPAI. Diperoleh dari http://www.kpai.go.id/berita/kpai-terima-aduan-26-ribu-kasus-bully-selama-2011-2017/

Pendergrass, W. S., \& Wright, M. (2014). Cyberbullied To Death: An Analysis Of Victims Taken From Recent Events. Issues in Information Systems, 15(1).

Saam, Z \& Sri, W. (2012). Psikologi Keperawatan. Jakarta: PT Raja Grafindo Persada.

Sobur, A. (2011). Psikologi Umum. Bandung: CV Pustaka Setia.

Soedjatmiko, S., Nurhamzah, W., Maureen, A., \& Wiguna, T. (2016). Gambaran bullying dan hubungannya dengan masalah emosi dan perilaku pada anak Sekolah Dasar. Sari Pediatri, 15(3), 174-80.

Surilena. (2016). Perilaku Bullying (Perundungan) pada Anak dan Remaja. CDK-236, 43(1), 35-38.

Susilowati. (2011). Hubungan Kegemukan Dengan Konsep Diri Pada Remaja Usia 16-18 Tahun (Studi Analitik Di SMA Negeri 2 Pare). Jurnal AKP, 4, 43.

Wiyani, N. A. (2012). Save Our Children from School Bullying. Yogyakarta: Arruz Media.

World Health Organization. (2017). Mental Health Status of Adolescents in South-East Asia: Evidence for Action. Diperoleh dari http://apps.who.int/iris/bitstream/handle/10665/254982/9789290225737eng.pdf;jsessionid=E212548CDFABCF58B308C2D731638EF5?sequence $=1$ 